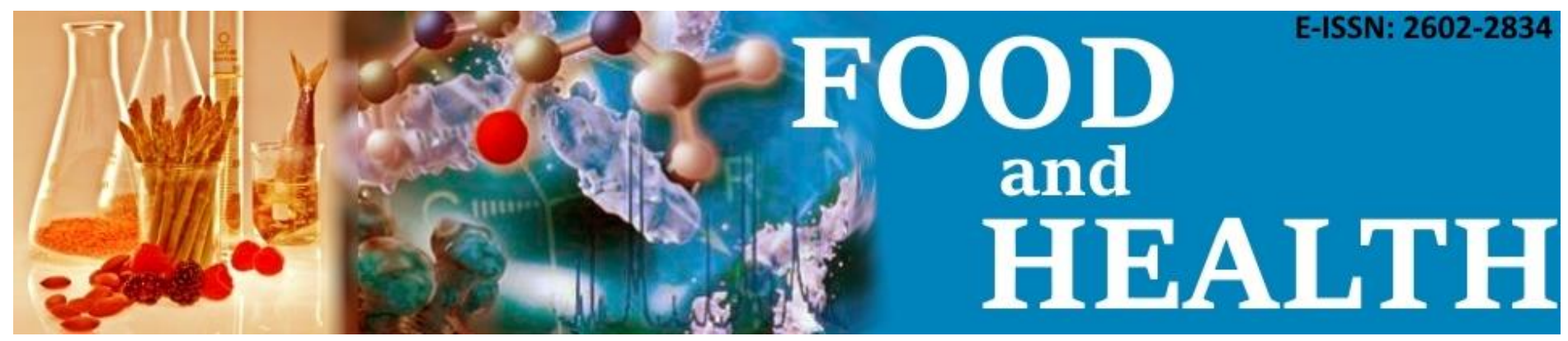

\title{
ENHANCEMENT OF BIOAVAILABLE MICRONUTRIENTS AND REDUCTION OF ANTINUTRIENTS IN FOODS WITH SOME PROCESSES
}

\section{Müge Hendek Ertop ${ }^{1 \text { iecio }}$, Müberra Bektaş ${ }^{2}$ id}

\section{Cite this article as:}

Hendek Ertop, M., Bektaş, M. (2018). Enhancement of Bioavailable Micronutrients and Reduction of Antinutrients in Foods with Some Processes. Food and Health, 4(3), 159-165. DOI: 10.3153/FH18016

\footnotetext{
${ }^{1}$ Department of Food Engineering, Faculty of Engineering and Architecture, Kastamonu University, Kuzeykent, 37000, Kastamonu, Turkey

${ }^{2}$ Department of Food Engineering, Faculty of Engineering and Natural Science, Gümüşhane University, Bağlarbaşı, 29000 Gümüşhane, Turkey
}

Submitted: 19.08 .2017

Accepted: 11.11.2017

Published online: 10.03.2018

Correspondence:

\section{Müge HENDEK ERTOP}

E-mail: muge_ertop@hotmail.com

๑Copyright 2018 by ScientificWebJournals

Available online at

www.scientificwebjournals.com

\begin{abstract}
The most of plant foods, nuts and cereals contain antinutrient compounds. They reduce to mineral bioavailability and protein absorption of foods thanks to their chelating properties. They causes to micronutrient malnutrition and mineral deficiencies. The micronutrient malnutrition is a widespread global health problem not only in developing but also in many countries. Increasing micronutrient intake in food through food processing based approaches is a sustainable method of prevention of micronutrient malnutrition which should be achieved through food diversification. There are traditional and technological methods that provide reducing of antinutrient compounds. The pretreatment and processing techniques as soaking, fermentation, germination, debranning, and autoclaving are even traditional methods which use generally in consumption of foods.Removing antinutrients, the bioavailability of some cation $(\mathrm{Ca}, \mathrm{Fe}$ and $\mathrm{Zn}$ ) and the absorption of proteins make to increase and consequently nutrition value of food increase. It is possible to reduce antinutrient factors by using domestic or industrial basic food processing techniques alone or in combination. This review focused on various methods to reduce antinutrients in food such as phytic acid, tannin, and oxalate in food grain to improve nutritional quality of foods.
\end{abstract}

Keywords: Micronutrients, Antinutrients, Digestibility, Bioavailability 


\section{Introduction}

The malnutrition influences more than half of the world population, especially in developing countries in which the plants to be a major source of food. The deficiencies of micronutrients such as minerals and vitamins have caused to be most serious health problems (Jorge et al., 2008). The solely total micronutrient content is not important in foods, their bioavailability is more effective factor than their level. In unrefined foods the low bioavailability of minerals causes metabolic disorder related to these nutritional factors. Therefore improving the nutritional value of such type of foods will improve the nutritional status of the population (Steiner et al., 2007; Gupta et al., 2015).

Phytate has long been recognized as an antinutritional factor affecting the bioavailability of major minerals such as $\mathrm{Ca}$ and trace ones such as $\mathrm{Fe}, \mathrm{Cu}, \mathrm{Zn}$ and $\mathrm{Mn}$. Other antinutrients of importance in foods are tannins, polyphenols, oxalats and tripsins. The known that they limit the bioavailability of food materials (Eltayeb et al., 2007). Decreasing of antinutritional factors is very advantageous, due to their influences on nutrition. However, many antinutrients besides their primary effects on the bioavailability of nutrients may also be toxic beyond a certain dose, for example oxalate or cyanogenic acid. Therefore interest has grown to reduce their antinutritional effects nowadays (Novak and Haslberger, 2000).

Soaking, dehulling, cooking and fermentation are important traditional methods used to reduce antinutrients. Furthermore germination and fermentation enhance the nutritional value of cereals ad legumes by causing significant changes in chemical composition and elimination of antinutritional factors (Abdelrahaman et al., 2005).

The aim of this review was to evaluate the effect of processing methods which can be decrease the level of antinutrients such as phytic acid, polyphenols and tannin which are mostly found in food materials.

\section{Antinutrients in Foods}

The compounds such as phytic acid, tanin and polyphenols found in leguminous, vegetables and cereal grains are known as anti-nutritional factors affecting the bioavailability of proteins, minor minerals such as $\mathrm{Zn}, \mathrm{Fe}, \mathrm{Cu}$ and major minerals such as $\mathrm{Ca}$ and $\mathrm{P}$. Antinutrients reduce the maximum utilization of nutrients (especially proteins, vitamins or minerals), and as a consequence they obstruct an optimal bioavailibility of the nutrients present in a food and decrease its nutritive value (Eltayeb et al., 2007).
Phytic acid myoinositol is 1,2,3,4,5,6-hexa dihydrogen phosphate. It is the major storage form of phosphorous comprising $1-5 \%$ by weight in cereals, nuts and legumes (Vats and Banerjee, 2004). Moreover it include 50-85\% of total phosphorous in plants (Reddy et al., 1982). Cereals, legumes, oil seeds, hard shelled fruits, which are necessary in human nutrition, are the considerable phytic acid sources. They represents approximately $40 \%$ and $60 \%$ of total calorie intake for daily human diet (Schlemmer et al., 2009). Especially cereals and cereal products are rich in phytic acid content. In cereal grains such as wheat and rice, it is generally found in bran fraction such as aleurone layer and pericarp, in corn it is seen in endosperm (Gupta et al., 2015). It was reported that the phytic acid concentration in wheat germ and wheat bran are $1.1-3.9 \%$ and $2.0-5.3 \%$ respectively (Kasim and Edwards, 1998). The phytic acid content is upto $8.7 \%$ in rice bran (Lehrfeld, 1994; Zhang and Bai, 2014). Therefore, the rafination of the cereals significantly effect to phytic acid content (Suma and Urooj, 2014). The phytic acid content varies from approximately $1.0-5.4 \%$ of the other group oilseeds which includes soybeans, sesame seeds, sunflower kernels, linseeds and rape seeds (Lolas et al., 1976). Another group of foods contained phytic acid is nuts such as walnuts, almond, in which phytic acid content ranged from approx. 0.1-9.4\% (Chen, 2004; VenktachalamandSathe, 2006; Schlemmer et al., 2009). Phytic acid acts blocking the absorption of minerals such as $\mathrm{Fe}, \mathrm{Zn}$, and $\mathrm{Ca}$. For that reason it also named antinutritive agent. This binding phenomonia caused to insoluble salt form with poor bioavailability of minerals (Urbano et al., 2000; Feil, 2001).

Another antinutrient groups in foods are tannins and free phenolics. In terms of human nutrition, the content of both tannins and total free phenolics are not desirable for human consumption. Whereas phytic acid reduces the bioavailability of some essential minerals, tannins inhibit the digestibility of protein (Rehman and Shah, 2001). It was reported that, phenolic compounds decreased the digestibility of proteins, carbohydrates and the bioavailability of vitamins such as vitamin B12 and minerals (Liener, 1994). They also decreases the activity of digestive enzymes such as trypsin, chymotrypsin lipase and $\alpha$ - amylase.

Oxalic acid is a dicarboxylic acid generally found in plants and animals. Besides dietary intake it in the human body may also be derived from metabolism of ascorbic acid and glyoxylate. The previously conducted studies reported that star fruit, spinach, amaranth, bamboo shoot, ginger, almond, cashew, pine nut, hazel and peanut contained high levels of 
oxalateas. Moreover, water spinach, Chinese wolfberry, black glutinous rice, dragon fruit, rice bean, abalone fruit and Chinese torreya fruit were also presented as high oxalate-foods (Ruan et al., 2013). The consumption of high amount of oxalate could be fatal, because of oxalosis or the formation of calcium oxalate deposits in vital tissues or organs of the body (Sanz and Reig, 1992). The oxalate intake should be to less than 40-50 mg per day recommended by the American Dietetic Association, (2005) for the patients with kidney stone problems.

\section{Technological Processes and Changes in Antinutrients Content}

Most of the anti nutritive substances become ineffective or their level can be reduced with simple treatments such as heating, soaking, germination or autoclaving.

\section{Milling and Debranning}

Milling is the most commonly used method to remove the bran layer from grains. Furthermore this technique removes the antinutrients such as phytic acid but also has major disadvantages as it also removes major parts of minerals and dietary fibers (Gupta et al., 2015).

\section{Soaking}

The soaking is an easy method used generally in daily life and an important method helped in germination and fermentation of cereals. During soaking, phytase enzyme activates and effects to antinutrient compounds. Soaking process has both physical and chemical positive effects in structure of foods. For this reason, cereals such as chickpea, wheat and barley used to product in daily life should be consumed after soaked for a while (Gupta et al., 2015).

This method is the complete submergence of grains in water for a certain soaking period which results in the activation of endogenous phytases. The endogenous phytases are present in grains naturally. So by activation of these enzymes with several treatment such as soaking it has been reported that significant amount of phytic acid content in grains have been removed. Soaking is widely applied and most important method in germination and fermentation process of cereals. Furthermore it is a pretreatment before cooking for all grains. Soaking of cereals with endogenous or exogenous phytase increases in vitro solubility of minerals such as $\mathrm{Fe}$ and $\mathrm{Zn}$ by $2-23 \%$ (Lestienne et al., 2005).

In this method, the soaking water's heat and soaking time act significant. In a study conducted by Greiner and Konietzny (2006), soaking at temperature between $45^{\circ} \mathrm{C}$ and $65^{\circ} \mathrm{C}$ and $\mathrm{pH}$ value between 5 and 6 a considerable percentage of phytate was hydrolysed. The grains and beans soaking is quite effective for increasing in mineral and protein bioavailability as well as reduction of phytic acid (Coulibaly et al., 2011). The soaking duration and the combination with other treatments such as cooking are more effective that the only usage of soaking. As soaking time increased from $2 \mathrm{~h}$ to $12 \mathrm{~h}$ phytic acid content in chick pea decrease by $47.4 \%$ to $55.71 \%$ has been reported (Ertas and Turker, 2014).

On the other hand disadvantages of treatment, it can be disappearing of water soluble protein and minerals.

\section{Fermentation}

Fermentation is the one of the important processes that decrease the levels of antinutrients in food grains and increase minerals extractability, in-vitro protein digestibility and nutritive value of grains. The reduction in phytic acid during fermentation could be attributed to the action of the enzyme phytase released by microorganisms' fermentation. Therefore cereals based foods certainly should be consumed after fermentation treatment. It reduces amounts of phytic acid, tannin, polyphenols with fermentation treatment and it increase food's mineral bioavailability and digestibility (Gupta et al., 2015).

Fermentation is the one of the processes that decrease the levels of antinutrients in food grains and increase minerals extractability (Badau et al., 2005). Fermentation of food grains improves bioavailability of minerals and proteins. The phytic acid is present in grains in the form of complexes with metal cations such as $\mathrm{Zn}, \mathrm{Fe}, \mathrm{Ca}$ and proteins. The enzymatic degradation of phytic acid requires an optimum $\mathrm{pH}$ (generally below $\mathrm{pH} 4.5$ ) which can be provided by natural fermentation such as be in sourdough fermentation (Hayta and Hendek Ertop, 2017). The degradation of phytic acid can increase the amount of soluble of minerals. It have been reported that fermentation of millet grain for $12 \mathrm{~h}$ and $24 \mathrm{~h}$ could reduce the food inhibitors, phytic acid and tannins (Coulibaly et al., 2011). The natural fermentation also named as spontan fermentation can achieve a large reduction in phytic acid in cereals and legumes by the action of microbial as well as grain phytases. Because, the phytases which is based on grain and microbiota act on phytic acid during fermentation. The combination of fermentation with other treatments such as germination are more effective that the only usage of fermentation. There was recorded that $88.3 \%$ reduction in phytate content when germinated pearl millet were fermented with mixed pure cultures of Saccharomyces diasticus, $S$. cerevisiae, Lactobacillus brevis and $L$. 
fermentum at $30{ }^{\circ} \mathrm{C}$ for $72 \mathrm{~h}$ (Kaur et al., 2014). Abdelrahaman et al. (2005) reported that, germination and fermentation enhance the nutritional value of pearl millet by causing significant changes in chemical composition and elimination of antinutritional factors.

\section{Germination}

Germination is highly effective method to reduction of phytic acid content by up to $40 \%$ (Masud et al., 2007). During the germination process, the endogenous enzyme activity which has phytate degrading ability increases. This condition provide to degradation and decline antinutrients as phytic acid. In non-germinated cereal and legume grains have a little endogenous activity (Greiner and Konietzny, 2006). In a study conducted by Marshall et al. (2011), cereal grains were screened for phytic acid content and found that germination for 10 days resulted in a significant reduction $(p<0.05)$ in the phytate contents of all cereal grains screened.

\section{Autoclaving and Cooking}

Autoclaving is heat treatment application. Together with application heat treatment to cereals or other vegetable goods, acidity increase and phytase enzyme activate. The most of foods become usefull and healty with heat treatment application in daily diet. All legumes and some cereals are usually cooked either by simple boiling or in a pressure cooker for their consuming. The literature is reported that simple boiling improves the nutritional quality of food grains due to reduction in antinutrients (Rehman and Shah, 2005).

The phytic acid content is greatly reduced during cooking and soaking (Vellingiri and Hans, 2010). Together soaking and cooking are much more effective to reduce phytic acid level than only soaking for a short duration (Vidal-Valverde et al., 1994). In a study, autoclave and microwave treatments decreased phytic acid content as they also increased total mineral content and $\mathrm{HCl}$-extractability of minerals in whole wheat bread (Mustafa and Adem, 2014).

It has been observed, by previous studies, that different cooking methods improve the nutritional quality of food legumes to various extents (Nielson, 1991; Chi-Fai et al., 1997). Singh (1993) reported that improvement in protein quality of pigeon was obtained after the partial removal of polyphenols as a result of a simple boiling method. In another study, it was founded that pressure cooking was more effective than ordinary cooking in reducing the antinutrients of black grams and mung beans (Kataria et al., 1989). Moreover it was revealed that the boiling and autoclaving in water improved the protein quality of winged beans due to reduction in the levels of antinutrients (Kadam et al., 1987). Rehman and Shah (2001), observed an improvement in protein digestibility of black grams due to removal of tannins after pressure cooking.

Furthermore, it was reported by earlier studies that cooking treatment improves the digestibility of starch through gelatinization and destruction of antinutrients (Mbofung et al., 1999; Rehman et al., 2001). The improvement in starch digestibility can based on due to hydrolysis of starch as a result of heat treatments. According to another phenomonia, partial removal of tannins and phytic acid probably is creates a large space within the matrix, which increased the susceptibility to enzymatic attack and consequently improves the digestibility of protein and starch after the cooking process (Rehman and Shah, 2005).

It has been shown that a significant difference in oxalate content was obtained according to cooking methods. For example, when the taro samples were boiled in water for 40 min, oxalate content decreased by at least $47 \%$. However, when the samples were baked at $180{ }^{\circ} \mathrm{C}$ for $40 \mathrm{~min}$, this treatment did not bring about a significant change in the oxalate level (Savage and Martensson, 2010).

It was reported that the toasting process resulted in a significant reduction in trypsin-inhibitor activity of the toasted meal of soybean relative to the seed (Novak and Haslberger, 2000).

According to different studies, among the various common processing methods, the autoclaving treatment was found to be more effective in reducing various antinutritional compounds (Shimelis and Raksihit, 2007; Vadivel et al., 2007; Doss et al., 2011). Doss et al. (2011), reported that the autoclaving, cooking and soaking processing methods were found to reduced significant levels of various antinutritioanl compounds such as total free phenolic respectively.

\section{Conclusion}

The processing methods of foods can significantly decrease antinutrients. Genetic improvement as well as several pretreatment methods such as fermentation, soaking, germination also improves nutritional quality. Further decrease in antinutritional factors can be obtained by the usage of various fermentation methods such as spontaneus fermentation named as sourdough method of the processed grains. Cost effective processes for commercial and industrial productions should be developed. Future researchs are needed to determine the optimal processing conditions and to appropriate delivery of phytase enzyme to foods. 
There are close negative corelation between the level of antinutrients and the biovailability of micronutrients. For that reason the studies for determination of in vitro bioavailability of micronutrients in foods should be also done.

Nowadays there has been consumer's tendency towards food types that are produced with unrefined grains, cereals and legumes such as whole wheat flour or wheat bran. In this respect, the bioavailability of foods containing different types of cereals and grain fractions has been expected to improve by the use of this processes.

\section{References}

Abdelrahaman, S.M., El Maki, H.B., Babiker, E.E., El Tinay, A.H. (2005). Effect of malt pretreatment followed by fermentation on antinutritional factors and $\mathrm{HCl}$ - Extractability of minerals of pearl millet cultivars. Journal of Food Technology, 3, 529-534.

American Dietetic Association (2005). Urolithiasis /urinary stones. In, ADA Nutrition Care Manual. Chicago IL. USA, 483-486.

Badau, M.H., Nkama, I., Jideani, A.I. (2005). Phytic acid content and hydrochloric acid extractability of minerals in pearl millet as affected by germination time and cultivar. Journal of Food Chemistry, 92, 425-435.

Chen, Q.C. (2004). Determination of phytic acid and inositol pentakis phosphate in foods by HPLC. Agricultural Food Chemistry, 52, 4604-4613

Chi-Fai, C., Peter, C.-Kc., Shing, W.Y. (1997). Effect of cooking on content of amino-acids and antinutrients in the Chinese indigenous legume seed. Journal of the Science of Food and Agriculture, 75, 447-452.

Coulibaly, A., Kouakou, B. Chen, J. (2011). Phytic acid in cereal grains: Healthy or harmful ways to reduce phytic acid in cereal grains and their effects on nutritional quality. American Journal of Plant Nutrition and Fertilization Technology, 1, 1-22.

Doss, A., Pugalenthi, M., Vadivel, V. G., Subhashini, G., Anitha Subash, R. (2011). Effects of processing technique on the nutritional composition and antinutrients content of under -utilized food legume Canavalia ensiformis L.DC. International Food Research Journal, 18(3), 965-970

Greiner, R., Konietzny, U. (2006). Phytase for food application. Food Technology Biotechnology, 44, 125-140.
Hayta, M., Hendek Ertop, M. (2017). Optimization of sourdough bread incorporation into wheat bread by response surface methodology: Bioactive and nutritional properties, International Journal of Food Science and Technology, 52(8), 18258-1835.

Eltayeb, M.M., Hassn, A.B., Sulieman, M.A., Babiker, E.E. (2007). Effect of processing followed by fermentation on antinutritional factors content of pearl millet (Pennisetum glaucum L.) cultivars. Pakistan Journal of Nutrition, 6 (5), 463-467

Ertas, N., Turker, S. (2014). Bulgur processes increase nutrition value: possible role in in-vitro protein digestability, phytic acid, trypsin inhibitor activity and mineral bioavailability. Journal of Food Science Technology, 51(7), 14011405.

Feil, B. (2001). Phytic acid. Journal of New Seeds, 3, 1-35.

Gupta, R.K., Gangoliya, S.S., Singh, N.K. (2015). Reduction of phytic acid and enhancement of bioavailable micronutrients in food grains. Journal of Food Science and Technology, 52 (2), 676-684.

Jorge E.M., Wolfgang, H.P., Peter, B. (2008). Biofortified crops to alleviate micronutrient malnutrition. Current Opinion Plant Biology, 11, 166-170.

Kadam, S.S., Smithard, R.R, Eyre, M.D., Armstrong, D.G. (1987). Effect of heat treatment on ntinutritional factors and quality of protein in winged beans. Journal of Science of Food and Agriculture, 39, 267-275.

Kasim, A.B., Edwards, H.M.J. (1998). The analysis of inositol phosphate forms in feed ingredients. Journal of the Science of Food and Agriculture, 76, 1-9.

Kataria, A., Chauhan, B.M., Punia, D. (1989). Antinutrients in amphidiloids (blackgram \& mung bean) varietal differences and effect of domestic processing and cooking. Plant Food and Human Nutrition, 39, 257-266.

Kaur, K.D., Jha, A., Sabikhi, L., Singh, A.K. (2014). Significance of coarse cereals in health and nutrition: a review. Journal of Food Science and Technology, 51(8), 1429-1441.

Lehrfeld, J. (1994). HPLC separation and quantitation of phytic acid and some inositol phosphates in foods: problems and solutions. Journal of Agricultural Food Chemistry, 42, 2726-2731. 
Lestienne, I., Caporiccio, B., Besancon, P., Rochette, I., Treche, S. (2005). Relative contribution of phytates, fibers and tannins to low iron and zinc in vitro solubility in pearl millet (Pennisetum glaucum) flour and grain fractions. Journal of Agricultural Food Chemistry, 53, 8342-8348.

Liener, I.E. (1994). Implications of antinutritional components in soybean foods. CRC Critical Reviews in Food Science and Nutrition, 34, 31-67.

Lolas, G.M., Palamidids, N., Markakis, P. (1976). The phytic acid - total phosphorus relationship in barley, oats, soybeans and wheat. Cereal Chemistry, 53, 867-871.

Marshall, A.A., Samuel, J.E., Mary, U.E., Inegbenose, G.I. (2011). Effect of germination on the phytase activity, phytate and total phosphorus contents of rice, maize, millet, sorghum and wheat. Journal of Food Science and Technology, 48, 724-729.

Masud, T., Mahmood, T., Latif, A., Sammi, S., Hameed, T. (2007). Influence of processing and cooking methodologies for reduction of phytic acid content in wheat (Triticum aestivum) varieties. Journal of Food Processing and Preservation, 31, 583-594.

Mbofung, C.M.F., Rigby, N., Waldron, K. (1999). Use of two varieties of hard-to-cook beans and cowpeas in the processing of Koki (a steamed legume product). Plant Food and Human Nutrition, 54, 131-150.

Mustafa, K.D., Adem, E. (2014). Comparison of autoclave, microwave, IR and UV-stabilization of whole wheat flour branny fractions upon the nutritional properties of whole wheat bread. Journal of Food Science and Technology, 51(1), 59-66.

Nielson, S.S. (1991). Digestibility of legume protein. Journal of the Food Technology, 45, 112-118.

Novak, W.K., Haslberger, A.G. (2000). Substantial equivalence of antinutrients and inherent plant toxins in genetically modifed novel foods. Food and Chemical Toxicology, 38, 473-483.

Reddy, N.R, Sathe, S.K., Salunkhe, D.K. (1982). Phytases in legumes and cereals. Advances in Food Research, 82, 192.
Rehman, Z.U., Salariya, A.M., Yasin, M., Zafar, S.I. (2001). Thermal heat processing effects on in vitro protein digestibility of chickpea (Cicer arietinum). Pakistan Journal of Science and Research, 53, 75-77.

Rehman, Z.U., Shah, W.H. (2001). Tannin contents and protein digestibility of black grams (Vigna mungo) after soaking and cooking. Plant Food and Human Nutrition, 56, 265273.

Rehman, Z.U., Shah, W.H. (2005). Thermal heat processing effects on antinutrients, protein and starch digestibility of food legumes. Food Chemistry, 91: 327-331.

Ruan, Q.Y., Zheng, X.Q., Chen, B.L., Xiao, Y., Peng, X.X., M, Leung, D.W., Liu, E.E. (2013). Determination of total oxalate contents of a great variety of foods commonly available in Southern China using an oxalate oxidase prepared from wheat bran. Journal of Food Composition and Analysis, 32, 6-11.

Sanz, P., Reig, R. (1992). Clinical and pathological findings in fatal plant oxalosis. The American Journal of Forensic Medicine and Pathology, 13, 342-345.

Savage, G.P., Martensson, L. (2010). Comparison of the estimates of the oxalate content of taro leaves and corms and a selection of Indian vegetables following hot water, hot acid and in vitro extraction methods. Journal of Food Composition and Analysis, 23, 113-117.

Schlemmer, U., Frolich, W., Prieto, R.M., Grases, F. (2009). Phytate in foods and significance for humans: food sources, intake, processing, bioavailability, protective role and analysis. Molecular Nutrition \& Food Research, 53, 330-375

Shimelis, E.A., Rakshit, S.K. (2007). Effect of processing on antinutrients and in vitro protein digestibility of kidney bean (Phaseolus vulgaris L.) varieties grown in East Africa. Food Chemistry, 103, 161-172.

Singh, U. (1993). Protein quality of pigeon pea as influenced by seed polyphenols and cooking process. Plant Food and Human Nutrition, 43, 171-179.

Steiner, T., Mosenthin, R., Zimmermann, B., Greiner, R., Roth, S. (2007). Distribution of phytase activity, total phosphorus and phytate phosphorus in legume seeds, cereals and cereal by-products as influenced by harvest year and cultivar. Animal Feed Science and Technology, 133, 320-334. 
Suma, P.F., Urooj, A. (2014). Nutrients, antinutrients and bioaccessible mineral content (invitro) of pearl millet as influenced by milling. Journal of Food Science and Technology, 51(4), 756-761.

Urbano, G., Lopez-Jurado, M., Aranda, P., Vidal-Valverde, C., Tenorio, E., Porres, J. (2000). The role of phytic acid in legumes: antinutrient or beneficial function?, Journal of Physiology and Biochemistry, 56, 283-294.

Vadivel, V., Pugalenthi, M., Megha, M. (2008). Biological evaluation of protein quality of raw and processed seeds of gila bean (Entada scendens Benth.) Tropical and Subtropical Agroecosystem, 8, 125-133.

Vats, P., Banerjee, U.C. (2004). Production studies and catalytic properties of phytases (myo-inositol-hexakis-phosphate phosphohydrolases): an overview. Enzyme and Microbial Technology, 35, 3-14.
Vellingiri, V., Hans, K.B. (2010). Effect of certain indigenous processing methods on the bioactive compounds of ten different wild type legume grains. Journal of Food Science and Technology, 49, 673-684.

Venktachalam, M., Sathe, S.K. (2006). Chemical composition of selected edible nut seeds. Journal of Agricultural, Food Chemistry, 54, 4705-4714.

Vidal-Valverde, C., Frias, J., Estrella, I., Gorospe, M.J., Ruiz, R., Bacon, J. (1994). Effect of processing on some antinutritional factors of lentils. Journal of Agricultural Food Chemistry, 42, 2291-2295.

Zhang, H.W., Bai, X.L. (2014). Optimization of extraction conditions for phytic acid from rice bran using response surface methodology and its antioxidant effects. Journal of Food Science and Technology, 51(2), 371-376. 